\title{
Analysis of Writing on Scientific Learning (Articles) in The PGMI UIN Jakarta
}

\author{
Lu'luil Maknun $^{1}$, Zulela $^{2}$, Maruf Akbar ${ }^{3}$ \\ \{ luluilmaknun_pd17s3@mahasiswa.unj.ac.id ${ }^{1}$, zulela@unj.ac.id², marufakbar@unj.ac.id ${ }^{3}$ \} \\ ${ }^{1,2,3}$ Universitas Negeri Jakarta, Indonesia
}

\begin{abstract}
Analysis of learning to write scientific papers (articles) is one of the needs analysis in research development of learning models. The purpose of this study was to determine the perceptions and expectations of students towards teaching writing articles in the UMI PGMI Jakarta Study Program. The research methodology in this research is qualitative. The research sample was 50 PGMI students spread over 5.7 and 9. semesters. The data collection technique was in the form of a questionnaire via Google Form. The results of research related to student perceptions showed that the majority $(62 \%)$ of students had never written an article and published it. But students use articles to complete lecture assignments. Students expect that article writing training and intensive guidance from competent lecturers will be held. By knowing these perceptions and expectations PGMI lecturers are expected to design appropriate learning models for learning to write articles.
\end{abstract}

Keywords: Learning, writing, articles.

\section{Introduction}

As one of the requirements for graduation from the Undergraduate Program, PGMI students are required to make scientific papers in the form of theses. The thesis is then modified into a research article that must be uploaded in the UIN repository. This means that every student must publish his scientific work even if only in an online library. The advantage of online publication is that scientific work can be accessed by anyone who needs it without being bound by time and space. While the drawback is, if the article is not in accordance with the general rules of writing the article, then readers who will use the article as a reference will get an article that is less feasible.

During this time, there were no specific subjects that discussed writing articles. Article writing material is obtained by students, one of them is only from a small portion of other lecture material. For example in the language skills which include listening, speaking, reading and writing skills. The article writing material is in the writing material, and that was only one meeting because the writing component itself was very much material.

Students do not learn how to create articles intensively, however students are never separated from articles because the assignments given by lecturers from other subjects, such as curriculum planning, require students to look for journal articles as a reference.

To improve students' skills and productivity in writing articles, the design of RPS and syllabus and other curriculum components are needed. Before designing an article writing learning model, it is necessary to analyze the learning needs of writing an article in the form of 
a questionnaire that can describe the perceptions and expectations of students in learning article writing.

The findings of this study are expected to be useful for PGMI lecturers, students and the UIN Jakarta academic community.

\section{Literature Review}

Articles are scientific papers that are rewritten from a study and distributed through publication in reputable journals.[1]

Generally the article component consists of the beginning, middle and end. The front of the article includes (1) the title, (2) the author's name, (3) the author's affiliation, (4) abstract and (5) keywords. The middle section which is the contents of the article consists of an introduction, discussion section and concluding section. The final part of an article includes the bibliography and appendix [2]

However, Rifai [3] argues that writing articles does not necessarily have to start from the introduction. Start writing from the easiest and most interesting part. Writing can also start from the preparation of tables or preparation of images. If the cultivation of a section is stuck, delay and move to another part that is ready to be handled. After everything is ready to be presented, then it is arranged according to the components that must be present in an article. Thus writing articles is not a hard Job.

Why do students still find it difficult to write articles? Syaefullah [4] explained that the difficulty factor for students in writing scientific papers / articles was because:

1. Weak basic ability of students to build knowledge construction in accordance with the basics of philosophy of science

2. The incomplete guidelines for scientific writing in explaining the way of scientific writing in accordance with the laws of knowledge in the dimensions of epistemology, ontology, and axiology (the fundamentals of scientific writing)

3. Lack of understanding the basics of philosophy of science and cognitivism

4. Weak understanding of students in the dimensions of research methodology

5. Lack of reading reference books that are relevant to the subject (scientific exploration)

6. Weak ability of students to use good and correct language rules.

There are several lecturers who in their lecturing activities require students to read journals. This academic policy certainly needs to be appreciated as an effort to popularize the interest in reading journals led by the public [5]

Various attempts were made to improve writing skills. Both at the college level and at the school level. Some research that has been done reveals that there is an increase in the skills of writing scientific papers / articles after the respondent is given certain treatments.

One study conducted by Zulkarnaini [6], stated that there was an increase in writing skills in scientific works through the Drill Method. Subsequent research was conducted by Tnunay [7] who used a problem-based learning model accompanied by portfolio assessment, the results of the study showed that there was a significant increase in article writing skills after respondents were treated with the model and assessment.

Another method that has been used is the mind map method conducted by Tebing et al [8] where through this method there is an increase in scientific writing skills. In line with that, Muhamad Fauzan [9] suggested that there was a relationship between character strengthening and the activity of writing scientific papers with the principle of 165 . 
Furthermore, research conducted by Irawadi [10] about the CIRC (Cooperative Integrated Reading and Composition) learning model in improving the ability to write scientific papers.

Supporting this research, $\mathrm{He}$ and Izziv [11] used the IMRAD (Introducition, Method, Research and Discussion) method as writing learning strategies. While Li and Zhang [12], and Fazillist [13] revealed the results of their research on the need for investigations in the writing process. The assessment in writing has been explored by Shirazi [14] and Walkinshaw [15]

In this connection, the steps of writing articles have been studied and discussed by Rumney [16], namely the techniques of seeing, doing and writing. Another strategy is the metacognitive strategy discussed by Cer [17]. Meanwhile, Like and Zhang[18] discussed how to editing writing.

Subsequent research on writing style, Lancaster [19] revealed, if we want students to perceive style and sound as social and dialogic, it makes sense to make assignments that encourage them to reflect deeply on their types. writer's self-representation is effective when writing to certain audiences in certain genres. Without the opportunity to reflect on it, students may be slower to understand the many voices they have learned to control and weave together in their own writing. Speeding up this capacity, and drawing students' explicit attention to it, can be a more liberating idea for many students than the more static "find their voice".

Regarding the relationship between writing and reading skills, McCardle [20] suggested that there is a relationship between reading activities and students' writing skills.

\section{Methodology}

Research Methodology The learning analysis of writing articles in PGMI is a descriptive qualitative method. The results of this analytical study are directed at students' perceptions and expectations towards learning to write articles. The population of this research is the students of PGMI UIN Jakarta in the 5th, 7th and 9th semesters. The sample of respondents is 50 students. The sampling technique of this study is purposive sampling, where each sample taken must meet certain criteria. the criteria in question is that the student has made a paper or article.

\section{Findings}

Based on the results of the questionnaire calculations that have been analyzed. Obtained the following results:

\section{a. Student Perception}

According to research data, there are $62 \%$ of students who have never written scientific papers in the form of articles and $38 \%$ who have written articles. In terms of article submission, $22 \%$ of students have submitted articles both for journals and competitions, the remaining $78 \%$ said they have never. That is, there are slices between students who have written articles and published them. Not all students who write articles submit these articles.

When asked if there were lecturers who had asked them to collaborate on making articles, the majority answered yes, the percentage was $56 \%$ and the remaining $44 \%$ answered no. This proves that the lecturer in making articles actually has involved students. But the students themselves do not know the procedures for making good 
articles, as evidenced by the percentage of students who know the procedures for making good articles is $48 \%$ and the remaining $52 \%$ claim to not know.

The majority of students also did not know how to send articles to a journal, this was answered by $82 \%$ of respondents and the remaining $18 \%$ knew how to submit articles to a journal. Related to this, there are 47 students who do not understand the style of a journal and 3 students who already know it.

In connection with that, related to the learning strategies that have been implemented so far, the majority of students answered that the learning strategies in PGMI lectures supported students to make articles. Respondents who answered "yes" were $80 \%$ and those who answered "no" were $20 \%$. The question is whether the learning media that has been used so far can support students to make articles, $74 \%$ answered yes and $26 \%$ answered no.

Evaluation of learning conducted so far at PGMI also actually has supported students to be productive in writing articles. Evidently $80 \%$ of students answered "yes" and $20 \%$ answered "no". This is in line with the subsequent statement that the pattern of assignments so far has supported students to make articles with the percentage of answers $82 \%$ answered yes and $12 \%$ of students answered no.

The next research data is that $100 \%$ or the whole sample responds that students use journals to complete lecture assignments. In terms of citing, $98 \%$ answered citing cited and $2 \%$ answering no.

Next, student knowledge about the Mendeley application; the majority of students do not know about the Mendeley application. Those who answered knew about $14 \%$ and those who did not know were $86 \%$. This is relevant to the answer to the next question about whether students are able to use the Mendeley application as one of the bibliographic applications, students who answer no are $94 \%$ and answer already know it as much as $6 \%$. This is one of the important findings so that how the lecturer then gives material about the application of mendeley to students.

UIN Jakarta facilitates students and lecturers with an online library. There are online journals that are subscribed and can be downloaded for free. Students who answered that they knew that the UIN library provided e journals that could be downloaded for free were $88 \%$ of respondents, the remaining $12 \%$ did not know. As for whether e journals subscribed to the UIN library can help students in doing their class assignments, the majority answered yes, which is $80 \%$ and those who answered not as much as $20 \%$. The main text should be written using Times New Roman, 10pt, fully justified. Italics can be used for emphasis and bold typeset should be avoided.

\section{b. Student Expectation}

Expectations are important data needed to formulate a policy. Student expectations in learning writing articles are summarized in the following points :

1. PGMI Study Program conducts basic training on article writing, so students can understand what must be included in an article.

2. After students are directed on how to write good articles, then students are assigned to make articles.

3. It is necessary to have an article writing workshop and assignment of making articles both individuals and groups. 
4. Students are taught the procedure (style of environment) of writing articles and how to submit articles to journals.

5. Hold a competition in writing scientific papers (articles).

6. Encourage students to publish their articles

7. Students want continuous training and monitoring of writing and submitting articles

8. There is an evaluation process so students know the shortcomings and errors in writing articles

9. There is a mandatory training to write articles

10. Availability of supporting facilities

11. Students form special study groups outside of class hours so they can explore about writing articles

12. Each subject recommends creating journal articles

In conclusion, students want guidance and training in writing articles, and procedures for sending them to journal editors, assigning both individuals and groups, holding discussions and competitions as well as monitoring and motivation to publish them.

\section{Discussions}

Based on the results of analysis of learning to write articles in the form of students' perceptions and expectations, several ideas emerged about the method of learning to write articles that contain novelty, in accordance with literary studies about learning to write articles that have been studied by previous researchers. In addition, ideas about the media, evaluation, assignment patterns and the results of this research (in the form of students' expectations) also became the basis for the PKTI (Training of Scientific Papers) at the PGMI Study Program on October 10, 2019.

\section{Conclusions}

Students' perceptions and expectations of the learning of writing articles at PGMI UIN is one of the basis or foundation for lecturers in formulating learning plans, methods and evaluation techniques. The research findings reveal that the methods, media and learning evaluation that have been carried out in the PGMI Study Program have supported students to make scientific papers / articles. Students generally have used journal articles to do their class assignments. However, many students are not yet skilled at making articles and do not know how to send them to journals. The next finding is that students do not yet know that there is an application such as Mendeley that can be used to make bibliography.

Students hope that there is ongoing training or workshops, which are monitored regularly, and then evaluated so that students know their mistakes and shortcomings. Students also hope that there is an intensive coaching process in sending articles to journals. In addition, students also want to have learning outside of class hours (a kind of discussion forum) to improve student skills in making articles. Finally, to encourage students to write articles, in addition to supporting facilities, an article writing competition should be held so that students are even more motivated.

\section{$7 \quad$ Acknowledgements}


Thanks are due to the Head of PGMI for allowing researchers to conduct research. And all PGMI students who have agreed to be respondents of this research.

\section{References}

[1] W. Wibowo, Menulis artikel ilmiah yang komunikatif. Jakarta: Bumi Aksara, 2018.

[2] E. Gani, Komponen-Komponen Karya Tulis Ilmiah. Bandung: Penerbit Pustaka Reka Cipta, 2013.

[3] M. A. Rifai, Pegangan gaya penulisan, penyuntingan dan penerbitan karya ilmiah Indonesia. Yogyakarta: Gadjah Mada University Press, 2011.

[4] P. D. A. Syaefullah, Prinsip Dasar Penyusunan Dan Penulisan Karya Tulis Ilmiah. Jakarta: Kompas Gramedia, 2015.

[5] F. Junaedi, Menulis Kreatif Panduan Penulisan Ilmiah. Jakarta: Prenadamedia Group, 2015.

[6] Zulkarnaini, "Peningkatan Kemampuan Menulis Karya Ilmiah Mahasiswa PGSD Semester I Melalui Drill Method,” Jupendas, vol. 1, no. 2, pp. 1-9, 2014.

[7] P. Tnunay, N. Dantes, and M. Yudana, "Pengaruh Model Pembelajaran Berbasis Masalah disertai Asesmen Portofolio Terhadap Kemampuan Menulis Karya Ilmiah," e-Journal Progr. Pascasarj. Univ. Pendidik. Ganesha, vol. 512, pp. 1-11, 2013.

[8] N. Tebing and T. Tahun, "Artikel penggunaan teknik peta pikiran," pp. 1-11, 2013.

[9] M. Fauzan, "Upaya pembangunan karakter mahasiswa stain pekalongan,” vol. 165, no. $9,2015$.

[10] M. H. Irawadi, I. N. Martha, and I. W. Wendra, "e-Journal Universitas Pendidikan Ganesha Jurusan Pendidikan Bahasa dan Sastra Indonesia ( Volume 3 No . 1 Tahun 2015 ) PENERAPAN MODEL PEMBELAJARAN COOPERATIVE INTEGRATED READING AND COMPOSITION ( CIRC ) UNTUK MENINGKATKAN HASIL BELAJAR SISWA DALAM MENULI," vol. 3, no. 1, pp. 1-11, 2015.

[11] U. Izziv, “Urbanistični inštitut Republike Slovenije," vol. 29, no. 2, pp. 5-6, 2019.

[12] X. Li and M. Zhang, "Rising to the Challenge: What Practicing Teachers Learned From a Process-Based Writing Project in a Graduate Capstone Seminar," 2015.

[13] A. M. Fazilatfar, S. E. Elhambakhsh, and H. Allami, "An Investigation of the Effects of Citation Instruction to Avoid Plagiarism in EFL Academic Writing Assignments," 2018.

[14] M. A. Shirazi, "For a Greater Good : Bias Analysis in Writing Assessment," 2019.

[15] I. Walkinshaw, T. Milford, and K. Freeman, "Individual Consultations : Academic Writing Outcomes for International Students," 2015.

[16] P. Rumney, J. Buttress, and I. Kuksa, "Seeing, Doing, Writing: The Write Here Project," 2016.

[17] T. He, "Personality Facets, Writing Strategy Use , and Writing Performance of College Students Learning English as a Foreign Language," 2019.

[18] L. Like and X. Zhang, "EFL Writers ' Reconstruction of Writing Beliefs in a Functional Linguistics-Based Curriculum : What Does the Trajectory," 2019.

[19] Z. Lancaster, "chapter six tr acking students ' de veloping conceptions of voice and st yle in writing," 2019.

[20] C. Author, R. H. Bahr, W. Nagy, B. Editor, P. Mccardle, and V. Connelly, "Writing Development in Struggling Learners," 2018. 